\title{
Energy utilization pattern by farming community in Pusa and Kalyanpur block of Samastipur district
}

VICKY KUMAR AND SANJAY KUMAR

Received : 31.07 .2017 ; Revised : 28.08.2017; Accepted : 14.09.2017

See end of the Paper for authors' affiliation Correspondence to :

\section{VICKY KUMAR}

College of Agricultural Engineering, Dr. Rajendra Prasad Central Agricultural University, PUSA (BIHAR) INDIA
-ABSTRACT : The energy is the primary source of livelihood all over the world. The significant resources of energy were found to be wood, liquefied petroleum gas (LPG), diesel/petrol and electricity in Pusa as well as in Kalyanpur block. Wood was found with a higher per cent of yearly energy availability in the study area. Energy availability per capita was higher in Kalyanpur block as compared to Pusa block. More than 50\% consumption of energy takes place in cooking and heating both blocks of the study area.Total energy consumed (MJ) varied from 15974.10 to 21137.40 and 20763.60 to 30711.90 in Pusa and Kalyanpur block, respectively. The total energy consumption / Energy consumed per ha (118832.60/21782.40 MJ) was higher in Kalyanpur block as compared to Pusa block, The significant proportion of energy consumed in seedbed preparation (about $50 \%$ ). In Pusa block and Kalyanpur block, major proportion of energy was consumed in seedbed preparation was $50.20 \%$ and $48.21 \%$ followed by $25.61 \%$ and $21.00 \%$ for threshing, $21.64 \%$ and $27.82 \%$ was for irrigation, $1.15 \%$ and $0.99 \%$ for harvesting, $0.92 \%$ and $0.80 \%$ for showing and transplanting and $0.45 \%$ and $1.15 \%$ for intercultural operation, respectively.This paper aims to analyse present energy utilization resources in the selected area and to evaluate energy utilization pattern in theselected area.

- KEY WORDS : Energy consumption, Calorific value, Mechanization, Per capita availability

- HOW TO CITE THIS PAPER : Kumar, Vicky and Kumar, Sanjay (2017). Energy utilization pattern by farming community in Pusa and Kalyanpur block of Samastipur district. Internat. J. Agric. Engg., 10(2) : 556-563, DOI: 10.15740/HAS/IJAE/10.2/556-563. 